\title{
Hak Atas Pembangunan Sebagai Hak Asasi Manusia
}

\author{
Suparman Marzuki
}

The increasing of an unequal realities based on the equality as asserted in the Universal Declaration of Human Rights is as result of development. Because the development in the states of third world (developing countries) which depended on market mechanism with its variety emerged many problems. It seems development did not depart from the human rights perspective. It did not only raise the impact including on poor society, but also emerged crisis in economic, politic, law and cultural, and crisis in all fields mentioned above influences on human life largely. In this sense, according to the writer to maintain human rights there is also human obligations. In the context of fulfilling the development rights the government and the people have human obligations to fill sphere of social, economic and cultural so the rights in development could be enjoyed by all without exception.

Konsep hak asasi manusia (HAM) seringkali disebut sebagai hasil sejarah yang besar dari kemenangan rakyat atas pemerintahan aristokratik yang dekaden, sebagaimana yang di dokumentasikan dalam Declaration de I'Home et du Citoyen yang lahir pada Revolusi Prancis 1789 ataupun sebagai hasil kemenangan revolusi borjuis Amerika Serikat pada tahun $177^{1}$. Itu sebabnya banyak pendapat menyatakan bahwa HAM adalah salah satu penemuan terindah dari borjuis

'Secara historis, pemikiran tentang HAM sudah muncul jauh sebelum itu, yaitu pada awal abad ke-13 sebagaimana termuat dalam dokumen Magna Charta (1215); kemudian juga ditemukan dalam Petition of Rights (1628), dan Bill of Rights (1689). Akan tetapi pemikiran HAM pada awalnya berkaitan dengan doktrin hukum alam bahwa manusia dengan sendirinya menyandang serangkaian hak alamiah yang kekal dan tidak dapat dicabut, ditinggalkan dan berkurang karena tuntutan hak ilahi. Pada awal perkembangannya, doktrin hukium alam lebih mengajarkan sisi kewajiban dan mengesampingkan ide sentral dari hak asasi manusia yang menekankan pada persamaan dan kemerdekaan. Barulah pada abad ke-17 landasan persamaan dan kebebasan diletakkan. Doktrin hukum alam ini mendapat kritik cukup intens dan keras pada abad ke-19 hingga awal abad ke-20. Sekalipun demikian, ide mengenai HAM tetap bertahan sebagaimana termanefestasikan dalam bentuk semangat anti perbudakan, anti kekerasan, perlindungan perburuhan, dan sebagainya. Barulah pada pasca PD. II, pemikiran mengenai hak-hak warganegara mengkristal menjadi gagasan HAM. Pembunuhan dan kerusuhan dahsyat yang ditimbulkan dari PD.II telah menggugah suatu kebulatan tekad masyarakat internasional untuk melakukan upaya-upaya preventif untuk mencegah perang dengan membangun suatu organisasi internasional yang sanggup meredakan krisis internasional serta menyediakan suatu forum untuk diskusi dan mediasi. Gagasan ini kemudian diwujudkan menjadi suatu organisasi PBB, yang kelak berperan penting dalam pengembangan perlindungan HAM. Melalui komisi HAM, PBB berhasil merumuskan Deklarasi Hak Asasi Manusia se Dunia (Universal Declaration of Human Rights) yang kemudian menjadi standar umum yang berlaku untuk seluruh rakyat dan negara mana pun. 
revolusioner muda dan merupakan slogan dalam perjuangan borjuis progresif melawan rejim-rejim feodal yang telah rapuh $^{2}$.

Kelahiran HAM disambut dengan penuh harap sebagai katalis paling kuat dan kreatif bagi harapan-harapan sosial dari rakyat yang selama ratusan tahun berada dalam tekanan rezim-rezim otoritarian lama di Eropa, dan merupakan simbol kokoh bagi aspirasi-aspirasi politik, moral, ekonomi dan sosial bagi masyarakat di banyak negara karena dari sanalah hak-hak manusia di tempatkan di tempatnya yang tertinggi yang tidak bisa diingkari, sebab pengingkaran terhadap HAM sebenarnya sama dengan mengingkari eksistensi manusia itu sendiri ${ }^{3}$

Gantungan harapan akan lahirnya peradaban yang dibangun berdasarkan paradigma humanistik telah sedemikian rupa menghiasi pikiran bangsa-bangsa besar jauh sebelum deklarasi PBB tentang HAM dimunculkan pada tahun $1948^{4}$. Di masa-masa awal kelahiran HAM, dominasi pandangan legalistik terhadap HAM sangat kuat, sehingga untuk waktu yang panjang, HAM selalu ditafsirkan. secara sempit, hanya terbatas pada HAM dalam bidang hukum. Antara lain yang dicakup dalam HAM tersebut adalah hak untuk mendapatkan peradilan yang adil dan tidak memihak, hak untuk tidak ditahan secara sewenang-wenang, hak untuk tidak disiksa dalam proses pemeriksaan dan hak untuk mendapat bantuan hukum 5 .

Kuatnya cara pandang demikian itu sangat terkait dengan situasi masa lalu semua bangsa-bangsa di manapun di dunia ini yang pernah mengalami pahitnya kehidupan di masa kekuasaan Raja-raja absolut karena pada ketika itu kesewenangwenangan kekuasaan memang mewujud dalam bentuk pengabaian hak-hak hukum, sehingga amat wajar bila kemudian tuntutan akan jaminan konstitusional di bidang hak-hak hukum paling di kedepankan. Sema-ngat persamaan dalam jaminan hukum di era itu sangat menjanjikan seolah-olah secara otomatis akan segera terpenuhi tanpa menunggu dan tergantung kepada sector-sektor kehidupan sosial yang lain, mesikpun kenyataan yang dihadapi menunjukkan yang sebaliknya karena segala jaminan hukum itu tidak dapat dinikmati sebanyak mungkin orang (masyarakat) akibat dari makin meluasnya ketimpanganketimpangan ekonomi dalam masyarakat. Jurang antara si kaya dan si miskin semakin melebar, sehingga prinisip nondiskriminasi, persamaan di depan hukum

${ }^{2}$ Lihat, Mulyana W. Kusumah (1982) dalam, Hak Asasi Manusia dan Struktur-Struktur dalam Masyarakat Indonesia, hal. 43, alumni, Bandung: Alumni.

3 Tarik menarik antara pandangan partikularistik dan universalistik sangat mewarnai wacana HAM bertahun-tahun. Untuk memahami lebih jauh argumen dasar perdebatan antara universalistik dan partikularistik mengenai HAM lihat antara lain, Jack Donnelli., 1989, Universal Human Rights in Theory and Practice, Ithaca-London: Cornell University Press, 1989, dan Rhoda E. Howard. HAM: (terjemahan), 2001, Penjelajahan Dalih Relativisme Budaya, Jakarta: Grafiti.

- Deklarasi Hak Asasi Manusia se-Dunia (Universal Declaration of Human Rights) terdiri dari 30 pasal yang menjabarkan hak-hak asasi dalam segala bidang.

${ }^{5}$ Lihat Deklarasi Universal HAM 1948, dan International Covenant on Civil and Political Rights (ICCPR). 
(equality before the law) sebagaimana tertera dalam deklarasi HAM universal rupanya hanya memperluas status quo, membuat yang kaya bertambah kaya sedang yang miskin menjadi tambah miskin. Akses terhadap keadilan tidak menjadi merata, karena asas persamaan di depan hukum itu pada dasarnya hanya menguntungkan orang kaya. ${ }^{6}$ Secara struktural akan bisa dibuktikan bahwa persamaan di depan hukum itu tidak begitu menolong lapisan termiskin karena kemiskinan' itu sendiri sudah merupakan jurang.pemisah. Asas persamaan di depan hukum yang diandaikan "netral" itu pada dasarnya hanya bisa berjalan jika ada persamaan dalam menikmati kehidupan sosial, ekonomi, politik dan kultural.

\section{Pembangunan dan Ketidaksamaan}

Meluasnya realitas ketidaksamaan di atas seruan persamaan sebagaimana ditegaskan dalam deklarasi HAM se-dunia itu justru akibat dari pembangunan ${ }^{7}$ karena pembangunan di negera-negara dunia ketiga yang banyak digantungkan kepada mekanisme pasar dengan segala macam variasinya ternyata dalam perkembangan telah banyak menimbulkan persoalan. Pembangunan tampak tidak ditempatkan dalam perspektif hak asasi manusia. Pembangunan tidak hanya telah menimbulkan dampak terhadap lapisan masyarakat miskin, tetapi lebih luas dari itu telah menimbulkan pelbagai krisis sosial ekonomi, politik, hukum dan cultural, yang pada gilirannya membawa implikasi bagi kehidupan manusia itu sendiri secara luas. Para perencana pembangunan banyak yang menutup mata terhadap ketidakadilan penguasaan atas sumber-sumber ekonomi yang pada dasarnya membuat konsep mekanisme pasar dalam situasi seperti itu hanya menghasilkan konsentrasi kekuasaan ekonomi di tangan segelintir kecil pengusaha dan penguasa yang menindas sebagian besar massa rakyat.

Dalam konteks itu pula, Modal Asing yang datang dalam pelbagai paket bantuan ekonomi dan hubungan-hubungan dagang internasional telah dinilai, terutama oleh kalangan penganut teori dependensia sebagai strategi negara-negara kapitalis maju melakukan penghisapan ekonomi dan sumber daya negara-negara dunia ketiga secara sistematis. ${ }^{8}$ Andre Gunder Frank,

\footnotetext{
${ }^{6}$ C.J.M. Schuyt, Keadilan dan Efektivitas dalam Pembangunan Kesempatan Hidup, (penerbitan tidak bertanggal).

7 Dalam tiga dasawarsa terahir ini "pembangunan" telah menjadi semacam "agama baru" ataupun ideologi baru bagi berjuta-juta rakyat di Dunia Ketiga. Pembangunan menjanjikan harapan bagi perubahan dan perbaikan nasib kehidupan manusia. Dan laksana "mantera", kata pembangunan melejit, menjadi topik utama hampir di setiap pembicaraan para penguasa di negara-negara tersebut. Seolah-olah pembangunan itu dengan sendirinya pasti baik, pasti berguna, dan pasti bermanfaat. Padahal istilah "pembangunan" bila dikaji lebih jauh, tidak ubahnya dari semacam "perubahan" yang bermakna dan berfungsi ganda: positif maupun negatif. Sangat tergantung kepada siapa yang mengubah dan diubah serta cara bagaimana perubahan itu terjadi.

${ }^{8}$ Bantuan ekonomi juga dinilai selain melumpuhkan prakarsa dan kebebasan bertindak negara-negara sedang berkembang dan menumbuhkan ketergantungan kepada modal dan produksi teknologis luar negeri, juga cenderung menciptakan elite baru di dalam masyarakatnya yang memperlebar jurang perbedaan yang memang sudah ada.
} 
sebagaimana dikutif Rigoberto D. Tigalo 9 misalnya, menyatakan bahwa pengerukan kekayaan ekonomi oleh negara-negara maju (center) terhadap negara satelit adalah diresapinya ekonomi domestik oleh negara-negara maju tersebut secara sistematis dan fundamental sehingga menguasai tidak hanya kekayaan ekonomi tetapi juga politik dan sosial.

Pandangan pembangunan dominan menempatkan manusia sebagai alat produksi yang maksimal. Produksi tidak lagi mengabdi kepada kehidupan, ia telah menjadi diktator. Manusia tidak lagi dididik untuk mengembangkan kemerdekaan dan kebebasannya, akan tetapi dikerahkan kepada peningkatan kebutuhan-kebutuhan materiil; sementara kebutuhan-kebutuhan manusiawi, seperti kebebasan dan tuntutan akan hak-hak kemanusiaan non-materiil lainnya harus ditekan sehingga yang terjadi adalah proses "penjinakan" dan pemandegan kreativitas

Fenomena serupa terjadi juga di Indonesia, terutama di era kekuasaan Orde Baru yang secara tegas berorientasi pada pertumbuhan ekonomi (economic growth) dalam arti meningkatkan produksi setinggi-tingginya dengan segala upaya. Pikiran tentang distribusi pendapatan yang lebih adil dianggap tidak tepat sama sekali, apalagi tentang keadilan sosial karena keadilan sosial dianggap sebagai keadaan yang dengan sendirinya datang bila pembangunan ekonomi berhasil. Dan karena pembangunan ekonomi menjadi segala-galanya maka semua jaminan harus disiapkan. Dalam hal ini jaminan yang paling menentukan adalah adanya keamanan yang stabil (stability and security).

Semua ancaman terhadap stabilitas sejak dini harus dihilangkan, dan kontrol serta pengawasan melalui pranata-pranata resmi ditingkatkan. Obsesi akan keamanan yang stabil ini dalam kenyataannya sering hadir sebagai momok yang membuat mesin kekuasaan tidak manusiawi. Akibatnya lahir ketakutan-ketakutan, melemahnya daya kreativitas masyarakat, terampasnya pelbagai hak-hak dasar manusia, dan pelbagai aspek pengecualian-pengecualian lainnya. Dengan kata lain pembangunan telah menimbulkan dampak-dampak kemanusian di level hak-hak politik, sosial dan ekonomi, termasuk hak-hak kultural masyarakat, meskipun konstitusi (UUD 1945) secara tegas menyatakan bahwa bangsa Indonesia adalah bangsa yang berkeadilan sosial. ${ }^{10}$

Apa yang tertera dalam UUD 1945 itu adalah garansi konstitusional yang

${ }^{9}$ Lihat Tulisan Rigoberto D. Tigalo, Prisma, Mei 1979.

${ }^{10}$ Kemudian daripada itu untuk membentuk suatu pemerintahan Negara Indonesia yang melindungi seluruh tumpah darah Indonesia dan untuk memajukan kesejahteraan umum, mencerdaskan kehidupan bangsa dan ikut melaksanakan ketertiban dunia yang berdasarkan kemerdekaan, perdamaian abadi dan keadilan sosial, maka disusunlah Kemerdekaan, kebangsaan Indonesia itu, dalam suatu Undang-Undang Dasar Negara Republik Indonesia, yang terbentuk dalam suatu susunan negara republik Indonesia yang berkedaulatan rakyat dengan berdasar kepada Ketuhanan yang Maha Esa, kemanusian yang adil dan beradab, persatuan Indonesia dan kerakyatan yang dipimpin oleh hikmat kebijaksanaan dalam permusyawaratan perwakilan, serta dengan mewujudkan suatu keadilan sosial bagi seluruh rakyat Indonesia. 
seharusnya dijabarkan ke dalam pelbagai kebijakan pembangunan yang dijalankan, tetapi kenyataan yang dihadapi sebaliknya. Pembangunan -sekali lagi- bukan mendatangkan kebahagian bagi sebanyak mungkin orang, tetapi menyenangkan segelintir kecil orang. " Pembangunan berjalan pincang dari satu daerah ke lain daerah; kemajuan masing-masing daerah terutama antara Pulau Jawa dan di luar Pulau Jawa sangat senjang, bahkan tidak berkembang sama sekali. Itu semua menimbulkan ketidakadilan dan sakit hati yang meluas hingga ke hati sanubari setiap warga masyarakat, yang akhirnya berubah menjadi luka dan kekerasan. ${ }^{12}$

Konsep negará kesatuan di atas keanekaragaman cultural mulai digugat. Taman bunga cultural nusantara mulai dirusak, dan Bhineka Tunggal Ika tinggal slogan kosong. Kita pun menyaksikan ketidakharmonisan antara kemajuan ekonomi dan kesatuan, antara diversity dan unity sehingga kekuasaan menjadi semakin sentralistis dan dinamika lokal menjadi berkurang. Apa yang terjadi adalah apa yang disebut vertical cultural integration seperti yang terjadi di Amerika Latin dan Suriname. ${ }^{13}$

Pembangunan telah pula mengikis dan bahkan merampas kekayaan-kekayaan cultural masyarakat lokal sebagai hak-hak dasar yang dijamin oleh prinsip-prinsip HAM Universal, seperti mengikisnya hakhak ulayat, hak-hak untuk melakukan praktik-praktik ritual, dan lain sebagainya. ${ }^{34}$ Program transmigrasi sebagai salah satu paket pembangunan, sebagai contoh, telah menimbulkan masalah cukup serius di pelbagai daerah. Irian Jaya misalnya; transmigrasi selain telah menimbulkan konflik penggunaan lahan, terusiknya tradisi lokal, pergeseran pola makanan pokok, yang lebih utama adalah terjadinya

"Kalangan ilmuan kritis sangat intens mengajukan kritik terhadap pilihan model pembangunan yang diterapkan di Indonesia semenjak era 1970-an sangat tajam. Mereka menyorot fenomena pertumbuhan ekonomi yang tinggi yang ternyata hanya dinikmati oleh 5 persen lapisan elit dan sedikit oleh sekitar 35 persen golongan menengah, namun 60 persen penduduk Indonesia masih hidup dalam keadaan kemiskinan absolut.

${ }^{12}$ Apa yang terjadi di Sambas, Pontianak, Maluku (sekadar contoh) adalah kekerasan yang telah lama disemai dan dipupuk oleh kebijakan pembangunan yang tidak adil dan tidak merata.

${ }^{13}$ R. Dobrn Reveles, "National Unity, Cultural Identity, and Human Rights and Development, sebuah laporan seminar mengenai "Human Rights and Their Promotion in The Caribbean" yang diselenggarakan oleh The International Commission of Jurists, Barbados, 1977.

${ }_{14}$ Dampak pembangunan pada masyarakat lokal tidak saja merebut hak rakyat atas tanah adat secara paksa tanpa rugi, tetapi proses ini telah turut membunuh semangat kekeluargaan dan kebersamaan yang sudah sejak turun temurun di miliki oleh pelbagai suku di Indonesia, seperti yang terjadi pada suku Asmat dan suku Marind di Irian Jaya. Penduduk suku Marind pada tahun 1900-an berjumlah 60.000 orang, tetapi pada tahun 1980-an hanya tinggal 20.000 orang. Menurut salah seorang pemuka suku Marind, kematian mereka disebabkan oleh penyakit kelamin dan flu sepanyol yang melanda mereka secara massal sementara pelayanan kesehatan tidak memadai, dan sekarang keterdesakan mereka itu ditambah lagi dengan arus pembangunan yang merampas hak-hak cultural. mereka (lihat T. Mulya Lubis, Prisma. No. 10 Oktober 1983, hal. 42. Lihat juga tulisan Ifdal Khasim, Hak Atas Tanah, dalam Dimensi Hak Asasi Manusia Perspektif dan Aksi, CESDA LP3ES, 2000. 
benturan kepentingan ekonomi antara transmigran dan penduduk asli. ${ }^{25}$ Pembangunan juga gagal mengangkat kehidupan sosial ekonomi masyarakat lokal (asli) akibat kebijakan pembangunan yang jelas-jelas hanya dapat direspon oleh para pendatang. Hasil penelitian Paul Harry ${ }^{16}$ menunjukkan adanya kesenjangan kemampuan antara masyarakat pendatang dan lokal dalam merespon pelayanan publik. Dalam penelitian itu diperlihatkan pula bahwa para pendatang rata-rata memiliki kemampuan sangat besar merespon pelayanan publik di sector pertanian, peternakan, bimas, dan koperasi; sementra penduduk asli hanya memiliki kemampuan besar dalam merespon pelayanan publik di sektor perikanan.

Efek lain dari itu semua adalah munculnya perasaan kalah dan imperioritas dari sukusuku asli itu. Kebanggaan mereka akan kehidupan cultural semakin memudar. Mereka tidak bisa berintegrasi dan berasimilasi, dan milih melarikan diri ke hutan-hutan sekedar menyelamatkan hidup mereka. Bahaya dari kekalahan cultural ini adalah terdesaknya mereka dalam kantong-kantong reservasi seperti suku Indian di Amerika atau Aborigin di Australia.

\section{Generasi Ketiga HAM : :}

Gambaran pahit kehidupan masyarakat di negara-negara dunia ketiga akibat pembangunan, termasuk di Indonesia sebagaimana telah digambarkan di atas, telah melahirkan gelombang atau generasi ketiga $^{17}$ hak asasi manusia, atau disebut juga dengan hak solidaritas. Hak ini dibela dengan gigih oleh negara-negara berkembang yang menginginkan terciptanya suatu tatanan ekonomi dan hukum internasional yang akan menjamin hak atas pembangunan (the right to development), hak atas bantuan penanggulangan bencana, hak atas perdamaian, dan hak atas lingkungan hidup yang baik.

Kemunculan generasi ketiga hak asasi manusia ini menunjukkan bahwa pengertian HAM telah bergeser dari semata-mata kepedulian akan perlindungan bagi individu dalam menghadapi absolutisme negara, kepada penciptaan kondisi sosial dan ekonomi yang diperhitungkan akan memungkinkan individu mengembangkan potensinya sampai maksimal.

Dalam kaitan itulah, banyak sekali diajukan pertanyaan-pertanyaan dan pernyataan-pernyataan yang menggugat

${ }^{15}$ Lihat Loekman Soetrisno, The Problematic Role of Transmogration in the Sosial and Political Stabilization of Broader Areas: The Case of Irian Jaya, dimuat dalam "Indonesia Repport-Culture \& Society Supplement", No. 2 December 1986.

${ }^{16}$ Paul Harry, Birokrasi Dalam Pembangunan Pertanian di Irian Jaya", dimuat dalam "Kritis" Jurnal UKSW Salatiga, hal. 53-57, No. 4 tahun V, April, 1991.

${ }^{17}$ Karel Vasak telah mengelompokkan perkembangan HAM berdasarkan slogan Revolusi Pranciz, "Kebebasan, Persamaan, dan Persaudaraan". Menurutnya, masing-masing slogan ini, sedikit banyak mencerminkan perkembangan dari katagori-katagori atau generasigenerasi hak yang berbeda. Kebebasan, atau hak-hak generasi pertama, diwakili oleh hak sipil dan politik. Persamaan, atau hak-hak generasi kedua, sejajar dengan perliñdungan bagi hak ekonomi, sosial dan budaya. Tentang ini lihat, Scott Davidson, 1994, Hak Ásasi Manusia, Jakarta: Grafiti, hal 8. 
konsep-konsep pembangunan dan strategi pembangunan yang diterapkan di negaranegara dunia ketiga, tidak terkecuali Indonesia dari perspektif HAM.

Pasal-pasal yang dituangkan di dalam DUHAM merupakan landasan bagi perumusan dua Kovenan pokok lainnya dari HAM yaitu, International Covenant on Civil and Political Rights ( ICCPR) dan International Covenant on Economic, Sosial and Cultural Rights (ICESCR) yang telah diratikasi oleh 142 negara, ${ }^{18}$ serta kovenankovenan lainnya yang telah diratifikasi oleh banyak negara, seperti Konvensi Hak-hak anak, Konvensi Anti penyiksaan, Konvensi penghapusan segala bentuk diskriminasi, dan sebagainya.

Meskipun DUHAM memasukkan acuanacuan pada semua katagori hak sipil, politik, ekonomi, sosial dan kultural di dalam kerangka satu instrumen saja, ternyata adalah mustahil mendapatkan kesepakatan di antara negara-negara anggota-anggota PBB untuk menyusun sebuah dokumen hukum yang mengikat, yang mencakup semua jenis hak yang mengikat yang mencakup semua jenis hak yang tercantum dalam deklarasi itu. Sementara sebagian negara berargumentasi bahwa semua jenis hak itu membentuk suatu kesatuan yang tidak dapat dipecah-pecah dan saling mendukung satu sama lain, sebagian yang lain-terutama Amerika Serikat dan Inggris-berpendapat bahwa hak sipil dan politik dapat segera dipaksanakan dan berkekuatan hukum, sedangkan hak ekonomi, sosial dan kultural bergantung pada implementasi yang pasti dan terprogram. ${ }^{19}$

Negara-negara Barat, yang struktur politik dan ekonominya sangat dipengaruhi oleh konstitusionalisme revolusioner abad ke-17 dan ke-18, berkilah bahwa adalah wajar apabila dalam waktu dekat ini kita hanya dapat mengharapkan hak-hak generasi pertamakebebasan dari campur tangan negarasaja yang di proteksi oleh hukum internasional. Hak ekonomi, sosial dan budaya tidak cukup diproteksi seperti itu, dan paling baik dipenuhi melalui sistem laporan yang progresif. Pada akhirnya, penyusunan dua kovenan, yang masingmasing mengenai satu dari kedua katagori hak yang luas itu, tampaknya mendukung pernyataan yang diberikan oleh negaranegara Barat itu. Sementara hak-hak sosial dan politik segera saja memberikan proteksi dengan mengharuskan negaranegara untuk "menghormati" hak-hak yang diakui dan menjamin hak-hak itu bagi semua individu yang berada di dalam wilayahnya dan tunduk pada yurisdiksinya. ${ }^{20}$ Sementara hak-hak sosial, ekonomi dan budaya hanya mensyaratkan

${ }^{18}$ Indonesia sampai sekarang belum menjadi pihak dari perjanjian multilateral ini. Padahal di era Orde Baru Indonesia paling vokal berbicara mengenai pentingnya hak-hak ekonomi, sosial dan budaya di forum-forum internasional untuk menjawab tuduhan organisasi HAM internasional atas keadaan HAM di Indonesia.

${ }^{19}$ Lihat Asbjorn Eide, Hak-Hak Ekonomi, Sosial, dan Budaya Sebagai Hak Asasi Manusia, dalam Ifdal Khasim dan Johanes da Masenys Arus (ed)., 2001, Hak ekonomi, Sosial, Budaya Esai-Esai Pilihan (buku 2), Jakarta: Elsam.

${ }^{20}$ Pasal 2 (1). 
bahwa negara-negara "berjanji" akan mengambil langkah-langkah semaksimal sumberdaya mereka yang ada, dalam rangka mewujudkan sepenuhnya hak-hak yang diakui itu secara progresif. ${ }^{21}$

Perbedaan komitment diantara negaranegara terhadap dua kovenan itu tampak sebagai pembedaan yang mengada-ada, ${ }^{22}$ karena menganggap pemenuhan hak-hak sosial, ekonomi dan budaya membutuhkan pengeluaran produk domestik bruto (GDP) negara dalam proporsi yang lebih besar, yang tidak sebesar untuk pemenuhan hakhak sosial politik jelas tidak beralasan karena pada kenyataannya meminta biaya yang juga besar. Hak atas pengadilan yang jujur, misalnya, mensyaratkan terpeliharanya sistem peradilan yang efektif, tersedianya pembela yang dibiaya negara, dibiayainya penerjemah untuk orang-orang yang bahasnya bukanlah bahasa negara tempat ia di adili.

Keberatan banyak negara, termasuk Amerika Serikat untuk meratifikasi hak sosial, ekonomi, dan budaya ini jelas terkait dengan konsekuensi-konsekuensi ekonomi oleh karena kewajiban negara yang telah meratifikasi konvensi ini terkait dengan kewajiban memberikan hak atas standar hidup yang layak, termasuk hak pangan, hak atas kepemilikan, hak untuk bekerja dan hak dalam pekerjaan, hak atas pendidikan, dan hak atas kesehatan.

Meskipun silang sengketa tentang keberadaan hak-hak sosial, ekonomi dan budaya hingga sekarang masih acapkali muncul, Sidang Umum PBB tidak berhenti mengembangkan konsep universalitas HAM. PBB terus bergerak dengan mengumumkan apa yang disebut hak solidaritas, yaitu hak atas lingkungan yang sehat, hak atas perdamaian, hak atas pangan, hak atas kepemilikan bersama atas warisan umat manusia, dan yang paling penting, hak atas pembangunan. ${ }^{23}$ Sidang Umum PBB perlu waktu lama untuk mengakui hak ini, sampai pada tahun 1979 ketika PBB menyatakan bahwa "hak atas pembangunan adalah hak asasi manusia" dan bahwa "kesempatan yang sama atas pembangunan adalah hak prerogatif dari negara maupun individu-individu dari suatu negara".

Gagasan tersebut dinyatakan dengan lebih jelas ketika pada tahun 1986 Sidang Umum PBB menyetujui deklarasi tentang Hak atas Pembangunan yang menyatakan bahwa "manusia adalah subyek utama dari pembangunan dan harus menjadi partisipan yang aktif dan memperoleh keuntungan dari hak atas pembangunan". ${ }^{24}$ Dengan instrumen yang sama, Sidang

\section{${ }^{21}$ Ibid.}

${ }^{22}$ Kedua katagori hak-hak ini memang di atur dalam masing-masing kovenan. ICCPR menggunakan:..."undertakes to respect and to ensure to all individual within its territory and subject to its jurisdiction the rights recognized in the present covenant...(pasal 2(1); sementara CESCR menggunakan formulasi:..."undertakes to take steps,...to the maximum of its available resources, with a view to achieving progressively the full realization of the rights recognized in the present covenant..." (pasal 2(1). Perbedaan formulasi inilah yang dijadikan dasar untuk menarik batas tegas terhadap kedua kovenan tersebut.

${ }^{23}$ Lihat "Deklarasi Vienna", Komnas HAM 1997.

${ }^{24}$ Ibid. 
Umum PBB menekankan tugas-tugas yang berhubungan dengan hak ini yang harus dilakukan negara: tugas untuk - merumuskan kebijakan pembangunan internasional, dan pada tingkat nasonal, tugas untuk menjamin tersedianya "akses kepada sumberdaya dasar, pendidikan, layanan kesehatan, pangan, perumahan, pekerjaan, dan distribusi pendapatan yang adil".

Konfrensi itu juga mengakui martabat yang inheren. dan kontributif dari masyarakat asli terhadap pembangunan serta pluralitas masyarakat, dan dengan tandas menegaskan kembali komitmen masyarakat internasional terhadap kesejahteraan ekonomi, sosial, dan budaya mereka, serta untuk memungkinkan mereka menikmati hasil dari pembangunan yang berkesinambungan. Negara harus menjamin adanya partisipasi masyarakat asli yang bebas dan seutuhnya dalam seluruh aspek masyarakat, terutama yang menyangkut hal-hal yang menjadi kepedulian masyarakat, terutama menyangkut hal-hal yang menjadi kepedulian mereka. ${ }^{25}$

Tercakup juga dalam hak-hak atas pembangunan adalah perlunya dijamin hak-hak pelestarian identitas cultural yang terpatri di dalam adat istiadat, bahasa, agama dan sebagainya. Dalam International Covenant on Economic, Sosial and
Cultural Rights (ICESCR) dinyatakan bahwa, All peoples have the rights of selfdetermination. By virtue of the right they freely determine their political status and freely pursue their economic, sosial and cultural development ${ }^{26}$

Pengertian pembangunan cultural di sini jelas bukan pengrusakan, penindasan atau pembunuhan cultural. Dalam pertumbuhan kehidupan cultural yang lebih luas hal itu mencakup semua lapisan, tetapi harus dipelihara, sekaligus mengagendakan perubahan-perubahan sosial ekonomi dan politik dengan perawatan kehidupan cultural lokal. Dan di dalam konteks ini kebijakan desentralisasi yang akan atau sedang diagendakan untuk dilakukan di Indonesia adalah momentum yang sangat tepat untuk menjadikan hak-hak atas pembangunan sebagai ideology pembangunan ke depan.

Oleh karena itu sangat tepat apabila pembangunan di era desentralisasi ${ }^{27}$ itu mulai menekankan pentingnya nilai-nilai etis. Pembangunan haruslah ditujukan terutama pada usaha perbaikan kualitatif bagi semua masyarakat dari segala kelompok serta pribadi-pribadi dalam suatu masyarakat. Sekalipun semua orang tentu harus memiliki barang-barang secukupnya agar bisa hidup sebagai manusia yang layak, tetapi ukuran sukses bagi suatu pembangunan bukanlah

${ }^{25}$ Ibid.

${ }^{26}$ Lihat juga pasal 3 yang menyatakan bahwa: “ The states parties to the present covenant undertake to ensure the equal of men and women to the enjoyment of all economic, social, and cultural rights setforth in this covenant".

${ }^{27}$ Kebijakan desentralisasi jelas memberi jalan bagi tumbuh kembangnya demokratisasi, meski sekaligus menyimpan bahaya besar apabila sentimen kedaerahan yang berlebihan menimbulkan "gairah" pembangunan yang tidak terkendali sehingga mengancam potensi daerah itu sendiri, termasuk potensi-potensi sosio-kultural lokal. 
kesuksesan pencapaian keberhasilan material, melainkan seberapa luas dan besar partisipasi rakyat untuk merencanakan dan mengendalikan perubahan, tanpa kehilangan dimensi substansial dari kemanusian itu sendiri.

Dalam rangka ini nilai-nilai etis dan manusiawi, menjadi pilihan yang lebih responship dengan prinsip-prinsip dasar kemanusian karena pembangunan sesungguhnya adalah pemerdekaan manusia dengan cara-cara yang manusiawi. Dalam kerangka itu maka terlalu riskan bila diserahkan begitu saja kepada pertimbangan-pertimbangan rasional para elit intelektual, teknokrat dan birokrat, politisi dan akademisi. Pembangunan sebagai proses pemerdekaan yang melibatkan totalitas manusia, bagaimanapun harus terus menerus ditempatkan di tengah-tengah arena pertimbangan-pertimbangan etis. Dan, pertimbangan-pertimbangan etis tersebut harus berakar pada keyakinan dasar bahwa manusia-sebagai individu dan kelompokterpanggil untuk menentukan dan memikul nasibnya sendiri.

Dengan demikian, partisipasi bukan semata-mata berdasarkan "kebaikan hati" para elit pengambil keputusan. Akan tetapi, partisipasi adalah hak dasar yang syah dari umat manusia. Dengan jalan ini ada harapan akan terbangun kesadaran kritis mempertahankan dan memperjuangkan hak-hak masyarakat. Partisipasi akan menerobos kubu kelemahan rakyat jelata, seraya menguakkan suatu kaki langit yang baru bahwa "ketidakberdayaan" mereka adalah akibat langsung dari'dominasi kelompok elit istimewa päda segala tingkatan. Dan pada gilirannya, kesadaran baru yang kritis itu pun akan melahirkan pengharapan yang merangsang perubahan hubungan-hubungan antara penguasa dan masyarakat. ${ }^{28}$

Partisipasi bukan hanya bermanfaat bagi masalah-masalah keadilan sosial, pemerataan, kesempatan kerja dan sebagainya. Ia pun berimplikasi positif pada pemeliharaan lingkungan hidup manusia. Karena pemburukan lingkungan hidup dewasa ini lebih besar diakibatkan oleh nafsu memiliki yang tidak terkendalikan dari sekelompok elit (penguasa dan pengusaha), sehingga dengan teknologi yang agresif dan eksploitatif kekayaan alam dikuras, hutan digunduli, pabrik-pabrik raksasa didirikan dan seterusnya. Akhirnya bermunculan implikasi susulan berupa krisis lingkungan, kekerasan, dan pelbagai bentuk krisis-krisis sosial lainnya.

\section{Penutup}

Setelah membahas cukup panjang mengenai hak asasi, untuk mempertahankan hak asasi maka dengan sendirinya ada pula kwajiban asasi. Dalam konteks terpenuhinya hak-hak pembangunan, maka pemerintah dan rakyat mempunyai kewajiban asasi untuk mengisi agenda sosial, ekonomi dan cultural sehingga hak-hak dalam pembangunan dapat dinikmati setiap orang tanpa terkecuali. hal. 38 .

${ }^{28}$ Maroelak Sihombing, Partisipasi Sebagai Pemerdekaan Manusia, Prisma, November 1990, 
Sebagai penutup, di bawah ini dikutip hasil Deklarasi Kwangju pada bulan May 1998 yang berhasil merumuskan apa yang disebut Asian. Human Rights Charter. Dalam salah satu bagian dari Charter itu disebutkan tentang The Right to Develpoment and Social Justice. Secara lengkap disebutkan: ${ }^{29}$

"every individual has the right to the basic necessities of life and to protection against abuse and exploitation. We all have the raight to literacy and knowledge, to food and clean water, shelter and to medical facilities for a healthy existence. All individuals and human groups are entitled to share the benefit of the progress of technology and of the growth of the world eceonomy"

"Development, for individuals and states, does not mean merely economic development. It means the realization of the full potential of the human person. Consequently they have the rights to artistic freedom. Freedom of expression and the cultivation of their cultural and spiritual capacities. It means the rights to participate in the affairs of the state and the community. It implies that states have the right to determine their own economic, social and cultural policies free from hegemonic pressures and influence".

Dari deklarasi itu tampak jelas bahwa, pembangunan haruslah ditujukan kepada pemenuhan dan perlindungan hak-hak dasar manusia (hak atas fasilitas dan pelayanan kesehatan yang baik, makan dan air bersih) termasuk hak-hak yang berkaitan dengan kebebasan untuk bereksperesi, mengembangkan potensi diri, dan sebagainya. Dan oleh karena itu pembangunan bukan semata-mata pembangunan ekonomi, tetapi pembangunan yang kondusif bagi tumbuh kembangnya pribadi-pribadi dan kelompok-kelompok manusia di dalam negara dan di dalam proses pembangunan yang menghormati, menghargai dan melindungi hak asasi manusia.

\section{Daftar Pustaka}

Brownlie, Ian (ed)., 1971, Basic Documents on Human Rights, Clarendon Press-Oxford.

Donnelli, Jack., 1989, Universal Human Rights in Theory and Practice, IthacaLondon: Cornell University Press.

Howard, E. Rhoda., 2000, HAM: Penjelajahan Dalih Relativisme Budaya, Jakarta: Grafiti.

Kasim, Ifdal dan Johanes da Masenus Arus (ed)., 2001, Hak Ekonomi, Sosial, Budaya Esai-Esao Pilihan (buku 2), Jakarta: Elsam Jakarta.

Kusumah, Mulyana., 1982, Hak Asasi Manusia \& Struktur-Struktur Dalam Masyarakat Indonesia, Bandung: Alumni.

Nadj E. Shobirin dan Naning Mardiniah (ed)., 200o, Dimensi Hak Asasi Manusia Perspektif dan Aksi, Jakarta: CESDA LP3ES.

Reveles, R. Dobrn., 1977, National Unity, Cultural Identity, and Human Rights \& Development, paper seminar yang

${ }^{29}$ Lihat Asian Human Rights Charter., 1999, A People's Charter (versi Inggris), cetakan. Kedua, hal. 16. 
diselenggarakan oleh The International Commission of Jurist, Barbados.

Schuyt, C.J.M, Keadilan dan Efektifitas

Dalam Pembangunan Kesempatan Hidup (Tanpa Penerbit dan Tahun)

Scott Davidson., 1994, Hak Asasi Manusia, Jakarta: Grafiti.

Indonesia Repport Culture \& Society

Supplement No. 2 tahun 1986.
Jurnal Kritis, No. 4. 1991. Kritis (jurnal), No. 4. 1991.

Prisma, Mei 1979.

Prisma, No. 10. 1983.

Prisma, 1990.

Deklarasi Vienna, Komnas HAM, 1997. Asian Human Rights Charter, A. People's Charter, 1999. ICCPR dan ICESCR. 